\title{
Minat Berwirausaha Ditinjau dari Kepribadian Extraversion pada Mahasiswa Fakultas Ekonomi Universitas Dharmawangsa Medan
}

\author{
Entrepreneurship Interest Between Extraversion Personality in \\ Students Faculty of Economics, Universitas Darmawangsa Medan
}

\author{
Sarinah* \\ *Universitas Prima Indonesia, Indonesia \\ * Corresponding author: sarinahlumbantoruan@gmail.com
}

\begin{abstract}
Abstrak
Penelitian ini bertujuan untuk mengetahui hubungan antara kepribadian extraversion dengan minat berwirausaha. Hipotesis yang diajukan dalam penelitian ini adalah adanya hubungan positif antara kepribadian extraversion dengan minat berwirausaha, dengan asumsi semakin extraversion kepribadian yang dimiliki individu, maka semakin tinggi minat berwirausaha, dan sebaliknya semakin lemah kepribadian extraversion yang dimiliki individu, maka semakin rendah minat berwirausaha. Subjek penelitian yang digunakan dalam penelitian ini adalah mahasiswa-mahasiswi Fakultas Ekonomi Universitas Dharmawangsa Medan sebanyak 125 orang yang dipilih dengan metode purposive sampling. Data diperoleh dari skala untuk mengukur kepribadian extraversion dan minat berwirausaha. Perhitungan dilakukan dengan melakukan uji prasyarat analisis (uji asumsi) yang terdiri dari uji normalitas dan uji linearitas. Analisis data yang digunakan adalah menggunakan korelasi Product Moment melalui bantuan SPSS 15 for Windows. Hasil analisis data menunjukkan koefisien korelasi sebesar 0,535 ( $<<0.05$ ). Ini menunjukkan ada hubungan positif antara kepribadian extraversion dengan minat berwirausaha. Hasil penelitian ini menunjukkan bahwa sumbangan yang diberikan variabel kepribadian extraversion terhadap minat berwirausaha adalah sebesar 28,6 persen, selebihnya 72,4 persen dipengaruhi oleh faktor lain seperti self efficacy, locus of control, lingkungan keluarga, pengetahuan kewirausahaan, dan motivasi berprestasi. Dari hasil penelitian ini dapat ditarik kesimpulan bahwa hipotesis penelitian ada hubungan positif antara kepribadian extraversion dengan minat berwirausaha dapat diterima.
\end{abstract}

Kata Kunci: Kepribadian Ekstraversi; Minat berwirausaha; Mahasiswa

\begin{abstract}
This study aims to determine the relationship between extraversion personality with entrepreneurhip interest. The hypothesis proposed in this research is a positive relationship between extraversion personality and entrepreneurship interest, assuming the extraversion of individual personality, the higher the entrepreneur interest, and the weaker the personality of extraversion owned by the individual, the lower the entrepreneur interest. Research subjects used in this study are students of Faculty of Economics, University of Dharmawangsa Medan as many as 125 people selected by purposive sampling method. Data were obtained from the scale to measure extraversion and entrepreneurship interests. The calculation is done by conducting prerequisite test analysis (assumption test) consisting of normality test and linearity test. Data analysis used is Product Moment correlation through SPSS 15 for Windows. The result of data analysis shows the correlation coefficient of 0,535 ( $p<0.05)$. This shows there is a positive relationship between extraversion personality and entrepreneurship interest. The results of this study indicate that the contribution of the extraversion personality variable to entrepreneurship interest is 28.6 percent, the rest 72.4 percent is influenced by other factors such as self efficacy, locus of control, family environment, entrepreneurship knowledge, and achievement motivation. From the results of this study can be concluded that the hypothesis of research there is a positive relationship between extraversion personality with entrepreneurship interests can be accepted.
\end{abstract}

Keyword: Extraversion Personality; Enterpreneurship Interest; Student College

How to Cite: Sarinah. 2017, Hubungan Motivasi Berprestasi dengan Prestasi Akademik pada Mahasiswa Fakultas Psikologi Universitas Prima Indonesia, Jurnal Diversita , 3 (1): 32-39. 


\section{PENDAHULUAN}

Pada era globalisasi, dunia dihadapkan pada keadaan dimana berbagai perubahan terjadi secara cepat di segala aspek kehidupan manusia. Dibutuhkan sumber daya manusia yang terdidik agar mampu bersaing di dunia globalisasi ini, sumber daya manusia yang terdidik dapat diperoleh dari perguruan tinggi. Perguruan tinggi dihadapkan pada kenyataan harus mampu merespons perubahan, memiliki komitmen membangun bangsa dengan kompetitif sehingga memiliki aksi dalam dunia global (Tambak, 2013).

Setiap tahunnya setiap universitas dan perguruan tinggi banyak menghasilkan tenaga ahli dan terampil, banyak di antara mereka yang tidak memperoleh tempat yang layak bagi kemampuan mereka sebagai hasil dari proses pendidikan (Jufri \& Wirawan, 2014). Banyak lulusan perguruan tinggi lebih memilih menjadi pencari kerja (job seeker) daripada menciptakan lapangan pekerjaan. Tidak mengherankan jika setiap tahunnya jumlah orang yang menganggur terus bertambah (Kasmir, 2006). Badan Pusat Statistik (BPS) melaporkan bahwa jumlah pengangguran untuk lulusan strata satu (S1) pada Februari 2015 meningkat menjadi 5,34 persen dibanding Februari tahun lalu yang hanya 4,31 persen. Begitu juga lulusan diploma mengalami peningkatan pengangguran dari 5,87 persen menjadi 7,49 persen (www.bps.go.id).

Tingginya tingkat

pengangguran dapat diatasi dengan penciptaan kerja langsung dalam bentuk kerja mandiri, usaha keluarga, atau usaha kecil (Suryana \& Bayu, 2010). Dengan menekuni dunia wirausaha sebenarnya banyak manfaat yang bisa diperoleh terutama terhadap pembangunan bangsa, yaitu: dapat mengatasi kesulitan lapangan pekerjaan, meningkatkan pendapatan masyarakat, sebagai pejuang bangsa dalam bidang ekonomi, meningkatkan ketahanan nasional dan mengurangi ketergantungan pada bangsa asing (Alma, 2011). Jumlah wirausaha di Indonesia masih sedikit, ditambah pula dengan minimnya mahasiswa yang ingin berwirausaha.

Perlunya perubahan sikap dan pandangan dari generasi muda terhadap dunia bisnis. Para remaja, para diploma, ataupun sarjana lulusan perguruan tinggi harus mulai mengarahkan pandangannya dan mulai terjun ke bidang bisnis karena pekerjaan bisnis cukup menjanjikan, dan untuk mengantisipasi pekerjaan bisnis, harus mempersiapkan bekal, berupa sikap mental dan menguasai beberapa keterampilan menunjang. Suryana (2006), mengatakan bahwa keberhasilan atau kegagalan wirausaha sangat dipengaruhi oleh sifat dan kepribadian individu. Banyak pendekatan yang dilakukan untuk mengkaji kepribadian. Salah satu diantaranya adalah dengan menggunakan pendekatan model lima faktor (big five personality).

Salah satu dimensi dari big five personality yang sangat berpengaruh dengan minat berwirausaha adalah dimensi extraversion. Para psikolog berpendapat bahwa kepribadian berhubungan dengan jenis karir yang dipilih seseorang dan bagaimana mereka berfungsi dalam pekerjaan ini (De Fruyt, dkk., dalam Pervin, dkk., 2010). Idenya adalah orang dengan karakteristik 
tertentu akan memilih pekerjaan tertentu dan akan berfungsi dengan lebih baik dalam beberapa pekerjaan dibandingkan pekerjaan lain. Merujuk pada model lima faktor, orang dengan tingkat extraversion yang tinggi akan lebih baik pada pekerjaan wirausaha. Individu yang extrovert adalah orang yang pandai dalam berhubungan dengan orang lain, sehingga cenderung mempunyai koneksi atau hubungan yang luas. Mempunyai kemampuan memahami secara mendalam kebutuhan orang lain serta kemampuan sosialisasi yang baik. Hubungan interpersonal yang baik dengan orang lain sangat diperlukan untuk menjadi seorang wirausaha.

Menurut Wiyono (2007), minat adalah keinginan yang kuat, gairah, dan kecenderungan hati yang sangat tinggi terhadap sesuatu. Minat adalah suatu dorongan yang menyebabkan terikatnya perhatian individu pada objek tertentu seperti pekerjaan, pelajaran, benda, dan orang. Minat berhubungan dengan aspek kognitif, afektif, dan motorik serta merupakan sumber motivasi untuk melakukan apa yang diinginkan (Jahja, 2011).

Menurut Sutjipto, (dalam Khairani, 2014), minat adalah kesadaran seorang terhadap suatu objek, orang, masalah, atau situasi yang mempunyai kaitan dengan dirinya. Artinya, minat harus dipandang sebagai sesuatu yang sadar. Oleh karena itu, minat merupakan aspek psikologis seseorang untuk menaruh perhatian yang tinggi terhadap kegiatan tertentu dan mendorong yang bersangkutan untuk melaksanakan kegiatan tersebut.

Wirausaha adalah istilah yang dipakai untuk menekankan pada jiwa dan semangat individu untuk melakukan kegiatan

kewirausahaan, yang diaplikasikan dalam segala aspek kehidupan (Alma, 2011). Berdasarkan pengertian minat dan wirausaha di atas maka dapat disimpulkan bahwa minat berwirausaha adalah kesadaran individu bahwa wirausaha menarik perhatiannya sehingga individu tersebut memberikan respon secara positif terhadap kegiatan wirausaha.

Alma (2005) mengungkapkan beberapa aspek-aspek minat berwirausaha, Yaitu, menanggung resiko yang ditunjukkan dengan ciriciri: Pengambilan resiko, suka pada tantangan, toleransi terhadap ketidakpastian jaminan pekerjaan, bermacam-macam krisis, dan berani menghadapi kegagalan tanpa rasa panik. Kreativitas, yang ditunjukkan dengan ciri-ciri: inovatif, fleksibel, dan penampilan diri yang positif. Kemandirian yang ditunjukkan dengan ciri-ciri: pengambilan inisiatif, yaitu sifat percaya diri terhadap kemampuan memecahkan masalah, kemampuan untuk berkomunikasi dengan menggunakan kata-kata yang efektif baik lisan maupun tertulis, komitmen. Orientasi ke masa depan yang ditunjukkan dengan ciri-ciri: perspektif jangka panjang dan orientasi pada tujuan atau hasil.

Adapun faktor-faktor yang mempengaruhi minat berwirausaha antara lain : (1) Kepribadian big five, chen., dkk (2012), dalam penelitiannya membuktikan bahwa individu yang memiliki kepribadian extraversion dapat mempengaruhi minat berwirausaha individu, (2) self efficacy, dalam penelitian yang dilakukan oleh Marini \& Hamidah (2014) menjelaskan self efficacy selalu berhubungan dan berdampak pada 
pemilihan perilaku individu termasuk pemilihan karir sebagai wirausahawan yang bermula dari minat berwirausaha. (3) locus of control, dalam penelitian yang dilakukan oleh Hermawan, dkk (2016), menyatakan bahwa locus of control adalah atribut psikologis yang berperan penting dalam menjadi wirausaha. (4) lingkungan keluarga, Aprilianty (2013), menunjukkan bahwa semakin tinggi dukungan lingkungan keluarga maka semakin tinggi pula minat berwirausaha siswa. (5) Pengetahuan kewirausahaan, Penelitian lain yang dilakukan oleh Ermawati \& Widodo (2015), dengan adanya pengetahuan memungkinkan manusia mengembangkan ketrampilan yang berguna bagi kehidupannya. Demikian halnya dengan pengetahuan kewirausahaan juga memiliki peran yang sangat penting dalam kegiatan kewirausahaan, karena pengatahuan kewirausahaan adalah dasar dari sumber daya kewirausahaan yang terdapat dalam diri individu.

Menurut Friedman \&

Schustack (2006), big five adalah pendekatan trait terhadap kepribadian yang diwakili oleh lima dimensi yaitu: extraversion, agreeableness, conscientiousness, neuroticism, dan openness. Salah satu dimensi yang berpengaruh terhadap minat berwirausaha adalah extraversion. Eysenck mengatakan kepribadian extraversion adalah istilah yang digunakan untuk menjelaskan orang-orang yang secara umum mudah bersosialisasi, aktif, ramah, mereka juga dianggap memiliki keterangsangan otak yang relatif berada pada tingkat lebih rendah dan cenderung mencari stimulasi (Friedman \& Schustack,
2006). Eysenck (dalam Pervin, 2010), juga menambahkan seorang individu yang bertipe kepribadian ekstrovert, orientasi jiwanya ke arah luar, kepada objek dan hubungan antar objek.

Menurut Jung, (dalam Feist \& Feist, 2010), kepribadian extraversion adalah sebuah sikap yang menjelaskan aliran psikis ke arah luar sehingga orang yang bersangkutan akan memiliki orientasi objektif dan menjauh dari subjektif. Sedangkan menurut Pervin, dkk., (2010), kepribadian extraversion merupakan salah satu ujung dari dimensi kepribadian introversiextraversi yang ditandai oleh disposisi untuk mudah bergaul, ramah, impulsif, dan berani mengambil resiko.

Costa \& Mccrae, (dalam Pervin, dkk., 2010), mengungkapkan dimensidimensi dari kepribadian Extraversion adalah (1) senang berteman, (2) level aktivitas, (3) ketegasan, (4) pencari kegairahan, (5) emosi positif dan (6) kehangatan.

Berdasarkan berbagai penelitian terdahulu yang telah dilakukan dan masalah-masalah yang terlah diuraikan, maka peneliti tertarik untuk melakukan penelitian dengan judul "Minat Berwirausaha Ditinjau dari Kepribadian Extraversion pada Mahasiswa/i di Fakultas Ekonomi Universitas Dharmawangsa Medan."

\section{METODE PENELITIAN}

Populasi dalam penelitian ini adalah mahasiswa/I Fakultas Ekonomi Universitas Dharmawangsa Medan yang berjumlah kurang lebih sebanyak 125 orang. Pemilihan sampel menggunakan metode purposive sampling. Pengumpulan data menggunakan pembagian skala, ,yaitu 
skala minat berwirausaha dan kepribadian extraversi, skala disusun dalam bentuk pernyataan dengan menggunakan skala Likert.

Analisis data menggunakan korelasi Product Moment dengan bantuan SPSS 15 for windows untuk mengetahui bagaimana hubungan antara variabel kepribadian extraversion dengan variabel minat berwirausaha.

\section{HASIL DAN PEMBAHASAN}

Sebelum dilakukan analisis product moment, data yang terkumpul terlebih dahulu ditentukam normalitas sebaran dan linieritas hubungannya. Dari uji normalitas dan uji linieritas diketahui bahwa hasilnya memenuhi asumsi tersebut. Hasil uji normalitas sebaran dan uji linieritas hubungan dapat diliat pada tabel 1 dan tabel 2 berikut ini:

\section{Tabel 1. Hasil Uji Normalitas}

\begin{tabular}{|l|l|l|l|l|l|}
\hline Var & SD & K- & Sig. & P & Ket \\
\hline $\begin{array}{l}\text { Minat } \\
\text { Berwir } \\
\text { ausaha }\end{array}$ & 7,512 & 1,044 & 0,113 & $\begin{array}{l}\text { P > } \\
0,05\end{array}$ & Sebaran \\
\hline $\begin{array}{l}\text { Keprib } \\
\text { adian } \\
\text { extrave } \\
\text { rion }\end{array}$ & 7,137 & 1,064 & 0,104 & 0,05 & normal \\
\hline
\end{tabular}

Data dikatakan berdistribusi normal jika $p>0.05$ (Priyatno, 2010). Uji normalitas yang dilakukan terhadap variabel minat berwirausaha diperoleh koefisien KS-Z = 1.044 dengan Sig sebesar 0.226 untuk uji 2 (dua) ekor dan Sig sebesar 0,113 untuk uji 1 (satu) ekor ( $p$ > 0.05), yang berarti bahwa data pada variabel minat berwirausaha memiliki sebaran atau berdistribusi normal. Uji normalitas pada variabel Kepribadian extraversion diperoleh koefisien $\mathrm{KS}-\mathrm{Z}=$ 1.064 dengan Sig sebesar 0.208 untuk uji 2 (dua) ekor dan Sig sebesar 0.104 untuk uji 1 (satu) ekor ( $p>0.05)$.

Tabel 2 Hasil Uji Linearitas Hubungan

\begin{tabular}{|l|l|l|l|}
\hline Variabel & F & Sig & Ket \\
\hline $\begin{array}{l}\text { Minat } \\
\text { berwirausaha } \\
\text { Kepribadian } \\
\text { extraversoni }\end{array}$ & 49.510 & 0.000 & Linear \\
\hline
\end{tabular}

Berdasarkan tabel 2 dapat dikatakan bahwa variabel minat berwirausaha dan kepribadian extraversion memiliki hubungan linear. Hal ini terlihat dari nilai $P$ yang diperoleh yaitu 0.000 maka $\mathrm{p}<0.05$ maka dapat disimpulkan adalah kedua variabel memiliki hubungan linear dan telah memenuhi syarat untuk dilakukan analisa korelasi Product Moment.

Hipotesis dalam penelitian ini berbunyi bahwa ada hubungan antara kepribadian extraversion dengan minat berwirausaha : ada hubungan positif yang signifikan antara kepribadian extraversion dengan minat berwirausaha pada mahasiswa Fakultas Ekonomi Universitas Dharmawangsa Medan Diasumsikan bahwa semakin extraversion kepribadian individu maka semakin tinggi minat berwirausaha individu dan sebaliknya semakin tidak extraversion kepribadian indidvidu maka semakin rendah minat berwirausaha

Tabel 3. Hasil Korelasi

\begin{tabular}{|l|l|l|}
\hline Analisis & $\begin{array}{l}\text { Pearson } \\
\text { Correlation }\end{array}$ & $\begin{array}{l}\text { Signifikansi } \\
(\mathrm{p})\end{array}$ \\
\hline Korelasi & 0.535 & 0.000 \\
\hline
\end{tabular}

Berdasarkan hasil analisis

korelasi antara kepribadian

extraversion dengan minat

berwirausaha, diperoleh koefisien korelasi 
product moment sebesar 0.535 dengan $\mathrm{p}$ sebesar 0.000 (p < 0.05). Hal ini menunjukkan bahwa adanya korelasi positif antara kepribadian extraversion dengan minat berwirausaha.

Dari hasil perhitungan tersebut, maka hipotesis yang diajukan dalam penelitian ini menunjukkan ada hubungan positif antara kepribadian extraversion dengan minat berwirausaha pada mahasiswa fakultas ekonomi Universitas Dharmawangsa diterima.

Hasil penelitian pada 125 mahasiswa fakultas ekonomi Universitas Dharmawangsa yang menjadi subjek penelitian maka diperoleh hasil bahwa ada hubungan positif antara minat berwirausaha dengan kepribadian extraversion dengan koefisien korelasi product moment sebesar $\mathrm{r}=0.535$, nilai $\mathrm{p}$ sebesar 0.000, artinya semakin extraversion kepribadian seseorang maka semakin tinggi minat berwirausaha individu dan sebaliknya.

\section{Tabel 4. Sumbangan Efektif}

\begin{tabular}{|l|l|l|l|l|}
\hline Model & $\mathrm{R}$ & $\begin{array}{l}R \\
\text { Square }\end{array}$ & $\begin{array}{l}\text { Adjusted } \\
\text { R Square }\end{array}$ & $\begin{array}{l}\text { Std. Error of } \\
\text { the Estimate }\end{array}$ \\
\hline 1 & $.535^{\mathrm{a}}$ & .286 & .280 & 6.373 \\
\hline
\end{tabular}

Dalam penelitian ini diperoleh koefisien determinasi $\left(\mathrm{r}^{2}\right)$ sebesar 0,286. Berdasarkan hasil tersebut, dapat disimpulkan bahwa 28,6\% kepribadian exraversion mempengaruhi minat berwirausaha dan selebihnya $72.4 \%$ dipengaruhi oleh faktor lain seperti self efficacy, locus of control, lingkungan keluarga, pengetahuan kewirausahaan, dan motivasi berprestasi.

Dengan demikian, dapat diambil kesimpulan bahwa semakin semakin extraversion kepribadian individu maka semakin tinggi minat berwirausaha individu dan sebaliknya semakin tidak extraversion kepribadian indidvidu maka semakin rendah minat berwirausaha.

\section{SIMPULAN}

Berdasarkan hasil-hasil yang telah diperoleh dalam penelitian ini, maka dapat disimpulkan sebagai berikut: Ada hubungan positif antara kepribadian extraversion dengan minat berwirausaha pada mahasiswamahasiswi Fakultas Ekonomi Universitas Dharmawangsa Medn dengan korelasi Product Moment ( $\mathrm{r}$ ) sebesar 0.535 dengan $p$ sebesar $0.000(p$ $<0.05$ ), artinya semakin semakin semakin extraversion kepribadian individu maka semakin tinggi minat berwirausaha individu dan sebaliknya semakin tidak extraversion kepribadian indidvidu maka semakin rendah minat berwirausaha.

Hasil penelitian ini menunjukkan bahwa sumbangan yang diberikan variabel kepribadian extraversion dengan minat berwirausaha adalah sebesar 28.6 persen, selebihnya 72.4 persen dipengaruhi oleh faktor lain yang tidak diteliti seperti lain seperti self efficacy, locus of control, lingkungan keluarga, pengetahuan kewirausahaan, dan motivasi berprestasi.

Dari kesimpulan yang telah dikemukakan, maka peneliti mengemukakan beberapa saran yang diharapkan akan berguna untuk kelanjutan studi korelasional ini.

Saran bagi mahasiswa agar mahasiswa-mahasiswi sebagai calon entrepreneur dapat memperkaya diri dengan ilmu kewirausahaan, mengembangkan nilai-nilai kepribadian 
wirausaha, untuk memulai membangun usaha sendiri.

Saran bagi perguruan tinggi agar universitas/perguruan tinggi khususnya Fakultas Ekonomi untuk mengajarkan program mata kuliah kewirausahaan khusus baik secara teori maupun praktik ataupun mengadakan pelatihan kewirausahaan, iklim wirausaha di kampus.

Saran bagi pemerintah diharapkan pemerintah terkait ataupun pihak-pihak swasta dapat mengadakan kompetisikompetisi bisnis, agar dapat dimanfaatkan mahasiswa untuk mengenalkan produknya atau untuk mendapatkan tambahan modal untuk berwirausaha dan saran bagi peneliti selanjutnya peneliti selanjutnya diharapkan dapat memilih subjek penelitian dengan melihat beberapa variabel kontrol seperti usia, kondisi ekonomi, latar belakang orang tua atau yang pernah mengikuti praktik wirausaha, dan peneliti selanjutnya juga diharapkan untuk meneliti dimensi-dimensi kepribadian Big five yang lain.

\section{DAFTAR PUSTAKA}

Alma, B. 2005. Kewirausahaan. Cet.kedelapan. Revisi. Bandung : Alfabeta.

Alma, B. 2011. Kewirausahaan. Bandung : Alfabeta.

Aprilianty, E. 2012. Pengaruh kepribadian Wirausaha, Pengetahuan Kewirausahaan \& Lingkungan terhadap Minat Berwirausaha Siswa SMK. Jurnal Pendidikan Vokasi. Vol. 2.No.3. diakses pada tanggal 21 Februari 2016.

dari Journal.uny.ac.id.

Chen,S.C, Jing, L.L. \& Sung, M.H. 2012. University Student's personality Traits and

Entrepreneural Intention : using Entrepreneurship and Entrepreneural attitude as Mediating Variable. Int. J. Eco. Res., 2012, v3i3, 76 - 82. diakses pada tanggal : 16 Maret 2016. dari www.ijeronline.com.
Ermawati. \& Widodo, J. 2015. Pengetahuan Wirausaha \& Kepercayaan Diri terhadap Minat Berwirausaha siswa Kelas XI jurusan pemasaran SMK Negeri 2 Semarang. Economic Education Analysis Journal. Vol.4. No.3. diakses pad tanggal 16 Maret 2016. dari http://journal.unnes.ac.id.

Feist, J., \& Feist, G.J. 2010. Teori Kepribadian. Jakarta: Salemba Humanika

Friedman, H.S., \& Schustack, M.W. 2006. Kepribadian Teori Klasik dan Riset Modern. Jakarta: Penerbit Erlangga.

Hermawan, R.W., Soetjipto, B.E., \& Rahayu, W.P. 2016. The effect of Entrepreneurial Self Efficacy \& Locus of Control on Entrepreneurship Interest through Entrepreneurship Literacy. IOSR Journal of Business and Management (IOSR-JBM). Vol 18, Issue 2. diakses pada tanggal 04 Mei 2016 dari www.iosjournals.org/iosrjbm/papers/vol 18issue2/versio n-1/t0182141148/pdf.

Jahja, Y. 2011. Psikologi Perkembangan Edisi Pertama. Jakarta : Kencana Prenada Media.

Jufri, M \& Wirawan, H. 2014. Internalisasi Jiwa Kewirausahaan Pada Anak. Jakarta : Kencana.

Kasmir. 2006. Kewirausahaan. Jakarta :RajaGrafindo Persada.

Khairani, H. M., 2014. Psikologi Belajar. Yogyakarta : Aswaja Pressindo.

Lubern, R., \& Terna, A. 2014. Personality Traits \& Emotional Intelligence as Predictors of Entrepreneurial Behavior Among Students of Benue State University. International Journal of Education and Research. Vol.2, No.7. diakses dari ( www.ijern.com/Journal/July/2014/46/p df)

Marini, C.K.,\& Hamidah, S. 2014. Pengaruh Self Efficacy, Lingkungan Keluarga, Lingkungan Sekolah terhadap Minat Berwirausaha Siwa SMK Jasa Boga. Jurnal Pendidikan vokasi. Vol.4, No. 2. diakses pada tanggal 21 februari 2016 dari http://journal.uny.ac.id

Pervine, L.A., Cervone, D., \& John, O.P. 2010. Psikologi Kepribadian: Teori \& Penelitian Edisi kesembilan. Jakarta: Kencana.

Suryana. 2006. Kewirausahaan. Jakarta, Salemba.

Suryana, Y., \& Bayu, K. 2010. Kewirausahaan: Pendekatan Karakteristik Wirausahawan Sukses. Jakarta : Kencana.

Tambak, S. 2013. Membangun Bangsa Melalui Pendidikan. Yogyakarta: Graha Ilmu 
JURNAL DIVERSITA, 3 (1) (2017): 32-39

Wiyono, E.H. 2007. Kamus Bahasa Indonesia Lengkap. Jakarta: Palenta.

Badan Pusat statistik (BPS). 2015. Jumlah Pengangguran 2015 .diakses pada tanggal 03 Maret 2016 dari http://bps.go.id/Brs/view/id/1158

Republika. 2015. Minat mahasiswa berwirausaha rendah. Diakses pada tanggal 24 Mei 2016 dari http://www.republika.co.id/ berita/ekonomi /makro/15/04/30minatmahasiswaberwirausaharendah. 